\title{
Research of Social and Cultural Changes and Innovation in China's National Dancing Art Education
}

\author{
Congyun Zheng \\ College of Music, Jiangxi University of Technology
}

Keywords: National culture; Dancing art; Dance education; Innovation research

\begin{abstract}
This paper takes dance education of the first professional dancing school in China Beijing Dance School as the research object, uses the basic theories of ethnology and sociology with basic principles of education as the guidance, puts the Chinese dance education at the historical background of social and cultural changes, reviews and summarizes the dance education for nearly half a century, so as to study how to adapt to the new situation, new environment and the tide of market economy, and provide the author's immature suggestion to further consolidate and develop China's national dance and cultivate more excellent dancing talents. With the economic globalization, the establishment of market economic system, the comprehensive construction of a well-off society, the implementation of the Western development strategy as well as the strengthening of materials civilization, political civilization and spiritual civilization construction, the Central Government attaches great importance to supporting and developing the cultural ind ustry, and brings good chance and great challenges to the development of dance culture and education. The author believes that China's dance education reform is facing two challenges: one is problems in the original teaching model that researchers have not solved or solved well, and another is the new issues.
\end{abstract}

\section{Introduction}

Education is the foundation of developing science and technology and cultivating talents, which plays a leading and global role in the modern construction, so it must be put on the strategic position of prior development. Fully implement the Party's education policy, adhere to the education service for socialist modernization construction, serve the people, combine with productive labor and social practice, and cultivate the comprehensive development of socialist builders and successors.

Innovation refers to an open concept, a flexible way of thinking, and as a result tailored to its business and the pursuit of efficiency, a respected institutional reality, and also a kind of continuous optimization, coordination, integration, and always in the best condition for sustainable development. Only by changing the mindset and the rigid pattern of development in the past, innovation will be worthy of the name.

Dance Instructional dance education, dance disciplines engaged in research are not rare, but mostly from the perspective of cultural teaching and research, and from the perspective of disciplines who rarely studied dance and dance education.

National dance art is a special culture phenomenon, which encompasses all aspects of traditional culture and study. It is human body that performs the mediation and dynamic art, and it is not subject to the limitations of language. It can communicate feelings and heart resonance between the dancers and the audience, it can be accumulated from ancient culture, inherit the national aesthetic 
psychology, values, and give birth to a new creation from the dancer's performance with the spirit of the times.

China's dance and dance education, as early as the beginning of the 20th century, has already begun under the influence of Western dance and dance education way.

With the rapid development of modern science and technology, information technology, it is hard to predict the change caused by the impact of the higher education. Therefore, according to the reality of folk dance art and folk dancing education, in the objective environment, it is essential to further strengthen the study of folk dance, folk dance education and development, innovation, and its significance is self-evident.

This paper first focuses on dance studies, theories and methods of Ethnology, namely and field work methods, which is the innovation of this paper. Second, in terms of talent training mode and curriculum development, on the basis of previous research, this paper proposed a new point of view. Thirdly, with regard to cultural industrialization, this paper puts forward feasible suggestions.

\section{Development of National Dance Education}

History is a continuous process. To understand the present education reform, you have to focus on education yesterday, because it is a product of the times, and it was forever indelible traces of history. Dance education can be divided into a mass dance and professional dance education by the different audiences and different purposes.

In the early 1950s shortly after the foundation of the new China, dance art in China has been developing at an unprecedented rate. Being established in 1950 at the Central Academy of drama, North China University dance team joined drama school of literary expansion, which established China's first dance.

As a national education in the large system of a branch, National dance education has its unique rule in teaching, and it needs not only the development of education needs the guidance of the scientific theory but also the discipline theory guidance. In order to accelerate the healthy development of the dancing art, the older generation of dancers strengthened the academic research, and had made a significant contribution to the theoretical research.

Dance material is an important part of dance education and teaching, and is a school in discipline construction in very heavy as the link. Early in the history of Ballet is a Ballet Academy in Paris, France, Beauchamp on the scale of the ballet training, especially in his specification on the five positions of the feet, the Ballet education plays a great role in Mauquy Muli bolaxisi textbook, gives great impetus to the development of Ballet, because large amount of today's ballet learning materials are derived from this.

Researchers are faced with a great era of both opportunities and challenges, how to fully inherit and carry forward the fine traditional culture, establish the values, aesthetics, ethics, and strengthen the national cohesion in the new historical period is a noble and arduous task.

Culture belongs to a nation and the core of a national culture is the cultural value recognized by this nation. Values are shared by a community or a group of people distinguishing between good and bad, right and wrong, or against the people's wishes, feasible and infeasible ideas along.

Folk dancing is a specific national social, historical and cultural product. With the development and changes of the times, and the enclosed conflict of social structure in modern civilization gradually disintegrated, the ancient layers of imagery and utilitarian content within it, has been unable to give new agers to spiritual transcendence, modern people cannot feel all the aesthetic 
sensibilities of predecessors in the creative process. An important part of the culture, folk dance needs to keep pace with the times and adapt to domestic and foreign markets, and adapt to globalization.

Under the background of economic globalization and knowledge economy in the world, strengthening international cultural understanding, exchanges and cooperation have become an inevitable trend. Schools of art, genre theory and introduction and penetration, influence and impact on national traditional culture speak for themselves.

Cultural heritage is the legacy of the national historical material and spiritual wealth. In history, there are colorful ethnic cultures, and the Chinese nation is an important part of cultural heritage protection. In China, ethnic minorities in the process of rapid social development and cultural change, endangered, extinction crisis facing ethnic minority cultural heritage is particularly serious, diversity of the protection of ethnic traditional culture has become a focus of attention problems.

For the historical and practical reasons, China's ethnic minority regions have maintained the backward traditions, which still hold people's hands and feet without external intervention and social liberalization, so it is obviously very difficult to start its modernization and development.

However, from the perspective of folk dance culture, there are too much to imitate and learn from the preservation and development of folk dance, which would certainly lead to adverse effects. The folk dances to modern, go-to-market process, in particular, to cherish the legacy of cultural elements and cultural nature, originality of culture, do not make the original's uniqueness and difference of traditional culture disappear, along with simply go commercial, performance, which makes the choreography left no shell-culture-cultural connotations.

From the functional view, culture and traditions determine everyone's code of conduct, values and ethics。 Under the great traditional influence, tradition flows in each person's "blood" through culture. Tradition is the essence of every type of culture, traditional culture, loses souls, lose yourself in

As an important part of the culture, folk dance is a kind of special body language to show emotional regulation and dissemination of artistic forms, which is a means of social interaction between man and man, between ethnic groups and ethnic groups. Meanwhile, as a social ideology, it always clearly reflects the grace, beliefs and ideals and aesthetic requirements, playing the educational role in society.

Therefore, researchers must pay attention to the development process of national economic and social development in the minority areas, be sure to attach great importance to relations between nationalities and ethnic groups, and hold a correct view of the national traditional culture, strengthen the nation's cultural exchange, and learn from each other. While fully using the cultural spreading and educational function, it is an intuitive audio-visual sleep art form to express emotions and pass culture of particularity. Both of them can reflect the spirit of times, and lose the national traditional culture connotation of excellent dance works, gradually pass the national emotional and culture changes of information to people, make them to form the traditional thought and consciousness concept, achieve great development caused by social structure transformation and culture of changes, from this national internal gradually to for, Avoided due to external force imposed upon ethnic minority areas, national feelings of intense exhibition swing to make socio-economic and cultural development in ethnic regions, carried out in a stable and harmonious environment, in order to achieve political and social stability in

So far, various dance groups in the country have not lost their administrative dependence on the 
State, its source of funding, staffing, infrastructure and many other aspects that are managed by the national Government, but they are featured by low level of industrial development, lacking self-adjusting, self-management, self-accumulation and development of skills.

With the further establishment of market economy system in China, taking the industrialization road of dance culture, I think the dance culture itself is the most effective mechanism for sustainable development, arts and culture and world culture is the dance a precondition for fully aligned.

Therefore, it is essential to take the following measures to promote the development of dance culture industry, and realize the industrialization of dance culture.

First of all, set up professional actors dance association from the perspective of resource sharing. In such a way, faceted can break down between the groups of "grey screen", strengthen exchanges and cooperation, make full use of limited human resources, and release the burden of staff for each dance professional groups.

Second, the dance culture industry regulations. On the one hand, dance industry laws and regulations for the construction of the cultural industry can regulate the dance industry with a legitimate business, on the other hand can protect the healthy development of the dance industry, as well as industry own self-discipline.

Third, based on the experience of foreign dance foundations, set up the dance foundation and cultural industry required by the development of dance culture industry, so that it can reduce the dance professional groups of the country's government support, strengthen the industry's own economic autonomy, to dance culture industry sex operation, economic foundation. Only in this way can form the scale effect of fund and talent advantages, in order to compete

In fact, dancing art education in the country, due to the effect of Soviet education mode directly, the beginning to the very model of vocational education development, is a typical product of planned economy. Under the absence made, while in training high, refined, tsim dance talent, has made great achievement, but its development speed, scale development, education reform, compared to other disciplines, is very slow.

In order to adapt to the trend of art to the market, planed and orderly way widen education professional, scientific construction further improved, fill the blank and deficiencies in the discipline construction. In terms of talents training target, great changes have taken place. For example, Guangdong dance school to primary and secondary school teachers from 1998 began to recruit the training target of dance bliss: in 2001 and opened in the face of the training of specialists in the field of dance education in teaching mode. In September 1991, Beijing dance academy affiliated dance school start for the Chinese opera directional training Chinese ballet actor's four-year experimental classes, try ballet actor training pattern and professional construction.

At present, the dance teaching category can be divided into outline type teaching, writing teaching material, dance spectrum textbooks, video teaching material etc. Early with outline type teaching material is given priority to, and later with video class materials. Any discipline teaching needs not only a certain number of teaching material but also substantial content, excellent and high quality materials, because of the particularity of dance discipline and slow construction of teaching material and early take materials to implement teaching outline type, therefore, often vary from person to person, because the entire content of the teaching materials are teachers. Therefore, researchers should ask the teacher to live dance teaching material in the form of words and images as much as possible to write, draw, or make video teaching material, so that as the basis of teaching and examination. 
Formed under the planned economy system earlier professional dance education system in the country, the educational aims are for professional groups whose primary purpose is developing dance artists. Therefore, the number of people access to dance education is very limited. Dance education is formed with the rapid social and economic system, which has been unable to meet the growing cultural needs of the people. In recent years, the development of China's private art schools is very fast. It is worth thinking about why it has such a boom.

Over the years, with the gradual improvement of living standards, growing people's pursuit of art and culture, apply for art school students plenty of growth, so, despite the many comprehensive colleges were here years art from social needs is still a big gap. Developing non-governmental arts education is the general trend. Although the existing private art colleges were stunted, but every year is increasing the number of applicants, from a side-note personnel market has great potential.

Although private schools in China have developed rapidly and already have a certain size and number, based on faculty and students, there is only "education edge" that can find your living space, or is still a long way to go even fighting for equal treatment, and there is no competition for public schools.

Creation of modern dance, Chinese dance article has had a very important impact. Neither idea nor the techniques, it is hard to make a breakthrough for Chinese folk dance itself due to the lack of scientific theories, only referring to the creation of new scientific theories, methods and thinking angle, fusion dance itself features will be ready for new developments. This gradually emerged in the national dance contest, which can see the impact. Development of dance education in China should not be a single dance or direction of Chinese folk dance and Ballet. Should be on the basis of their healthy development, reference and learning from each other in order to form a virtuous cycle. Professions must first have a tacit understanding.

Dance is the art of using body movements. Through organized and regular movements of the human body, through observation, experience and analysis of the nature or society, this paper then uses the concise forms and techniques, reflects some fresh women's characters and stories, or most people's lives, thoughts and feelings of the individual, which may be called a dance.

At present, the Chinese ethnic folk dances of various shapes, in addition to their independent of outside forms and manifestations, it settles deep in people's consciousness and social psychological mechanism for generations, its cultural inclusion is very complex and profound, from dancing to study on this subject may be poor and weak. Therefore, it should be a new, comprehensive, cross-cutting, edge learning research with more benefits.

Judging from the dance itself, first, United States modern dance master Duncan in the 1920s of the last century "betrays Jean creates a new dance classical ballet and modern dance's original intention was the one by one against the program of classical ballet of the Durance, free to let emotions in the midst of the action, vibrant life, to express deep down repressed passions.

Second, the art of dance to today, from the structure, content, and great changes have taken place in the form. From the original narrative dances, displays of emotion in the superficial sense of expression, gradually moving

Third, dancing as body art, mainly through body movements to express one's thoughts and emotions, and physical education are inextricably linked. Modern sports in the 20th century to achieve the rapid development of the world, especially China, from being insulted by foreigners before liberation as "sick man of Asia", became the envy of the world sports giants, the world is watching. 


\section{Conclusions}

According to statistics, it can be seen at various students from the art of dance, ethnic composition and less, accounted for a large proportion of Han Chinese students. Therefore, in the teaching of folk dance (including folk dances of the Han nationality, but mainly minority folk dance as the main content), Han minority students learn dance, culture, and history is a very important factor. Meanwhile, minority students who are not well aware of the nation's culture, history and customs, and so on.

Therefore, researchers should make full use of the research results, according to the progress of teaching and learning conditions, at some stages, videos and classroom teaching to the students on the spot to play and allow students to see their learning situation, compared with other students, identify the strengths and shortcomings. In this way, not just the teacher's teaching methods and methodological issues, it can also motivate students to actively participate in teaching, play the subjective initiative of students and promote the teaching and improving quality are good.

In short, making full use of modern technology and equipment, according to psychological research and dance teaching status, and constantly improve the original teaching methods, for $m$ a set of modern dance teaching methods, methods, improve the quality of teaching and the quality of talent, is the demand of the times, is also the dance education's requirements.

\section{References}

[1] Bamford A. The Wow Factor: Global research compendium on the impact of the arts in education[M]. Waxmann Verlag, 2006.

[2] Rudowicz E. Creativity and culture: A two way interaction[J]. Scandinavian journal of educational research, 2003, 47(3): 273-290.

[3] Wilson B. Of diagrams and rhizomes: Visual culture, conte mporary art, and the impossibility of mapping the content of art education[J]. Studies in Art Education, 2003: 214-229.

[4] Fang T. From" onion" to" ocean": Paradox and change in national cultures[J]. International Studies of Management and Organization, 2005, 35(4): 71-90.

[5] McKemmish S, Gilliland-Swetland A, Ketelaar E. Communities of Memory': Pluralising Archival Research and Education Agendas[J]. Archives and manuscripts, 2005, 33(1): 146.

[6] Prensky M. Digital natives, digital immigrants part 1[J]. On the horizon, 2001, 9(5): 1-6.

[7] Yang R, Vidovich L, Currie J. "Dancing in a cage": Changing autonomy in Chinese higher education[J]. Higher Education, 2007, 54(4): 575-592.

[8] Lubart T I. 17 Creativity Across Cultures[J]. Handbook of creativity, 1999: 339.

[9] Westwood R, Low D R. The multicultural muse culture, creativity and innovation[J]. International Journal of Cross Cultural Management, 2003, 3(2): 235-259.

[10] Tsui A S, Nifadkar S S, Ou A Y. Cross-national, cross-cultural organizational behavior research: Advances, gaps, and recommendations[J]. Journal of Management, 2007, 33(3): 426-478. 